\title{
Water for irrigation at the Antônio Conselheiro settlement, Mato Grosso, Brazil
}

\author{
Água para irrigação no assentamento Antônio Conselheiro, Mato Grosso, Brasil \\ Agua para irrigación en el asentamiento Antônio Conselheiro, Mato Grosso, Brasil
}

Received: 02/16/2022 | Reviewed: 02/18/2022 | Accept: 02/20/2022 | Published: 03/02/2022

\author{
Thaís Vasconcelos Silva \\ ORCID: https://orcid.org/0000-0003-1633-4331 \\ Instituto Federal do Matogrosso, Brasil \\ E-mail: thais.silva@jna.ifmt.edu.br \\ Tadeu Miranda de Queiroz \\ ORCID: https://orcid.org/0000-0002-1959-7658 \\ Universidade do Estado de Mato Grosso, Brasil \\ E-mail: tdmqueiroz@yahoo.com.br
}

\begin{abstract}
Irrigation is an essential technology for the increase in productivity, improvement of quality of produce, increase in producers' income, and the good quality of water is fundamental for the success of those benefits. The presence of salts in high concentrations may cause salinization of the soil, toxicity in plants and damage to irrigation equipment, such as sprinkler clogging, which causes environmental and economic losses. This study aimed at characterizing and classifying the quality of water for irrigation in the Antônio Conselheiro Settlement (AAC, in Portuguese) area, located in the state of Mato Grosso, Brazil. Samples were monthly collected from the main water sources in the area, the Sepotuba and Juba rivers, and Tarumã creek, from October 2014 to September 2015. The assessed variables were bicarbonate, calcium, chlorides, electric conductivity, magnesium, $\mathrm{pH}$, and sodium. The results were compared with the parameters established in the literature and were used to classify the waters by means of the Piper diagram and the United States Salinity Laboratory (USSL) diagram. Out of the assessed variables, only electric conductivity, $\mathrm{pH}$ and SAR presented restrictions to use in irrigation. The Piper diagram classification indicates the presence of chloride sodic waters $(59 \%)$, bicarbonate sodic waters (38\%), and mixed chloride waters (3\%). Good or excellent waters were found in $88.2 \%$. Therefore, the water available in the AAC area, in surface and underground sources, may be used in sprinkler and localized irrigation systems without major harm to the soil or to the crops.
\end{abstract}

Keywords: Rational use of water; Irrigation and salinity; Rural communities; Mato Grosso Pantanal.

\section{Resumo}

A irrigação é uma tecnologia essencial para o aumento da produtividade, melhoria da qualidade dos produtos, aumento da renda do produtor rural e para o sucesso destas é fundamental a boa qualidade da água. A presença de sais em grandes concentrações na água pode causar salinização do solo, toxidez nas plantas e danos aos equipamentos de irrigação como o entupimento de aspersores, o que acarreta prejuízos ambientais e econômicos. Objetivou-se com este trabalho caracterizar e classificar a qualidade da água para irrigação na área do Assentamento Antônio Conselheiro (AAC), localizado no estado de Mato Grosso. Coletou-se amostras nos principais mananciais da área, rios Sepotuba e Juba, e no ribeirão Tarumã, totalizando 29 pontos, mensalmente, no período de outubro de 2014 a setembro de 2015. As variáveis avaliadas foram bicarbonato, cálcio, cloretos, condutividade elétrica, magnésio, $\mathrm{pH}$ e sódio. Os resultados obtidos foram comparados com os parâmetros estabelecidos na literatura e utilizados para classificar as águas por meio do diagrama de Piper e diagrama do United States Salinity Laboratory (USSL). Das variáveis avaliadas, apenas condutividade elétrica, pH e RAS apresentaram restrições ao uso na irrigação. A classificação feita por meio do diagrama de Piper indica a presença de águas sódicas cloretadas (59\%), sódicas bicarbonatadas (38\%) e cloretadas mistas (3\%). Águas boas ou excelentes ocorreram em 88,2\%. Portanto, a água disponível na área do AAC, em fontes superficiais e subterrâneas, pode ser utilizada em sistemas de irrigação por aspersão e localizada, sem maiores prejuízos ao solo e às culturas.

Palavras-chave: Uso racional da água; Irrigação e salinidade; Comunidades rurais; Pantanal Mato-Grossense.

\section{Resumen}

La irrigación es una tecnología fundamental para incrementar la productividad, mejorar la calidad del producto, incrementar los ingresos de los productores rurales y la buena calidad del agua es fundamental para su éxito. La presencia de sales en altas concentraciones en el agua puede provocar salinización del suelo, toxicidad en las plantas y daños en los equipos de riego, como la obstrucción de los aspersores, lo que provoca pérdidas ambientales y económicas. El objetivo de este trabajo fue caracterizar y clasificar la calidad del agua para riego en el área del Asentamiento Antônio Conselheiro (AAC), ubicado en el estado de Mato Grosso. Se recolectaron muestras en las principales fuentes de agua de la zona, ríos Sepotuba y Juba, y en el arroyo Tarumã, totalizando 29 puntos, 
mensualmente, de octubre de 2014 a septiembre de 2015. Las variables evaluadas fueron bicarbonato, calcio, cloruros, conductividad eléctrica, magnesio, $\mathrm{pH}$ y sodio. Los resultados obtenidos se compararon con los parámetros establecidos en la literatura y se utilizaron para clasificar las aguas utilizando el diagrama de Piper y el diagrama del United States Salinity Laboratory (USSL). De las variables evaluadas, solo la conductividad eléctrica, pH y RAS presentaron restricciones de uso en riego. La clasificación realizada mediante el diagrama de Piper indica la presencia de agua sódica clorada (59\%), agua sódica bicarbonatada (38\%) y agua mezclada con cloruro (3\%). Aguas buenas o excelentes ocurrieron en $88,2 \%$. Por tanto, el agua disponible en la zona de la AAC, en fuentes superficiales y subterráneas, puede ser utilizada en sistemas de riego por aspersión y localizada, sin mayores daños al suelo y cultivos.

Palabras clave: Uso racional del agua; Riego y salinidad; Comunidades rurales; Pantanal Mato-Grossense.

\section{Introduction}

The Antônio Conselheiro Settlement (AAC, in Portuguese) is crossed by two great sources of surface waters, the Juba and Sepotuba Rivers, and by the Tarumã Creek, of smaller volume, whose basin is in its great part encompassed by the AAC area. Besides providing water to supply the rural properties near their riverbeds, these rivers are highly used for fishing and leisure activities, and the Juba Waterfall and Maciel Fall are their main tourist attractions.

Despite the abundance of water in these sources, in many areas of the settlement there are shortage problems. The region is characterized by a well-defined drought period, between the months of May and September (Dallacort, et al., 2011) which, combined with high temperatures, causes a dramatic reduction in the volume of water in small streams, many of which dry up. In those areas, the use of groundwater is fundamental to guarantee the water supply to the population, animals thirstquenching, and keeping agricultural practices.

The wells that draw groundwater in the AAC have various characteristics as to their depth, physical structure, pumping systems, and water quality, among others. In some rural properties, shallow wells do not have bricklaying in their inner walls, nor a masonry protective slab at their heads. Among the deeper wells, the construction pattern is uniform, tubulartyped; however, water quality is variable. It is common to find waters with an unpleasant taste due to salts in high concentration, as well as the typical smell of sulfur-based compounds.

The quality of the water used for irrigation and its availability (Silva, et al., 2019) are fundamental for the success in the use of irrigation systems. Therefore, it is necessary to know the water characteristics, which, in turn, will support the choice of the most adequate irrigation system for each situation, prioritizing the rational use of water resources (Seid \& Genanew, 2013; Gadanakis, et al., 2015).

The guidelines proposed by Ayers and Westcot (1985) for the interpretation of water quality are an important tool for better understanding its effects on soils and crops. Electric conductivity, sodium adsorption ratio (SAR), sodium concentration, chloride, bicarbonate and the $\mathrm{pH}$ level in water are among the variables used for identifying the presence of dissolved salts and ionic compounds, which may cause clogging of pipes and sprinkler heads, plant toxicity and soil salinization, thus impairing agricultural production.

Irrigation with saline waters may cause sodium accumulation in stems, roots and leaves; however, it does not significantly affect plant growth, as demonstrated by Araújo et al. (2014) for the cashew tree cultivation. The increase in irrigation water salinity did not influence other aspects, such as leaf humidity of the cowpea beans plant (Coelho J., et al., 2014) and the forage sorghum seed germination (Coelho D., et al., 2014). On the other hand, some species are sensitive to the increase in salinity, which may be manifested at the different stages of the plant life cycle, as observed by Diniz Neto et al. (2014) in the development of Licania rigida seedlings, and by Lima et al. (2014) in the growth and production of castor bean.

Water quality evaluation in the Curu River basin, in the State of Ceará, has demonstrated the increase in the concentration of salts in general, especially sodium. Urban and irrigated areas were the main responsible agents for the changes, revealing the negative influence of anthropic action on surface sources (Frota Junior, et al., 2007). The presence of 
chlorides in flowing water and groundwater is associated with the dissolution of rock-constituting minerals, as well as man's actions related to irrigation management, use of chlorine-based fertilizers (Fernandes, et al., 2005), and dumping of domestic and industrial sewage in nature (Zuffo, et al., 2009; Bazinet, 2010).

On the other hand, the use of saline waters in irrigation provides an input of nutrients into the soil. The salts contained in these waters are used by plants in their growth and development, and the use of fertilizers is often needed to supply the cultivation demand. Based on the assessment of the concentration of elements contained in irrigation water and the amount of salts necessary for the development of the cultivation, one may estimate the increase in their concentration in the soil (Nóbrega, et al., 2020).

Several enterprises, situated in the higher part of the basin, are established near the settlement. These include the Juba I and II hydroelectric plants, sugar cane, soy, corn, teak and pine monocultures, limestone quarries, as well as intensive and extensive farming. The municipality of Tangará da Serra has its domestic and industrial sewage destined to the Sepotuba River via its Ararão and Queima Pé tributaries. Paz et al. (2000) emphasize the importance of continuous monitoring of water and earth resources, which are essential to guarantee food security.

The implementation of irrigated systems, allied to practices of efficient use of water, combines benefits to the environment and to producers (Levidow, et al., 2014), as it enables the improvement in produce quality and in productivity (Kadyampakeni, et al., 2013; Silva, et al., 2020)). Despite its importance, hardly any farms in the AAC have any kinds of irrigation system, even if rudimentary. However, there is potential for the implementation of irrigation systems due to the local characteristics such as fruit and vegetable production, availability of water in sufficient quantity, among other factors.

Additionally, studies on water quality may be used for the analysis of environmental quality in general. The AAC area is placed in the Sepotuba River drainage basin, which, in turn, is one of the main contributors to the Paraguay Hydrographic Region. In this Region one may find the Pantanal, one of the largest continuous wetlands in the planet, for which the quality of water is fundamental.

In face of the information exposed above, this study aimed at characterizing and classifying the quality of water with a view to using irrigation systems in the Antônio Conselheiro Settlement in the State of Mato Grosso.

\section{Methodology}

The study was carried out in the Antônio Conselheiro Settlement (AAC), covering 39,202.02 hectares, located between the geographic coordinates $14^{\circ} 37^{\prime} 58,83^{\prime \prime}$ S to $14^{\circ} 59^{\prime} 08,14^{\prime \prime}$ S and $57^{\circ} 44^{\prime} 48,64^{\prime \prime} \mathrm{W}$ to $57^{\circ} 43^{\prime} 55,90^{\prime \prime} \mathrm{W}$. This area covers part of the Barra do Bugres, Nova Olímpia and Tangará da Serra municipalities (Figure 1) in the State of Mato Grosso. 
Figure 1 - Location of the Antônio Conselheiro Settlement (AAC) in the Tangará da Serra, Nova Olímpia and Barra do Bugres municipalities, State of Mato Grosso.

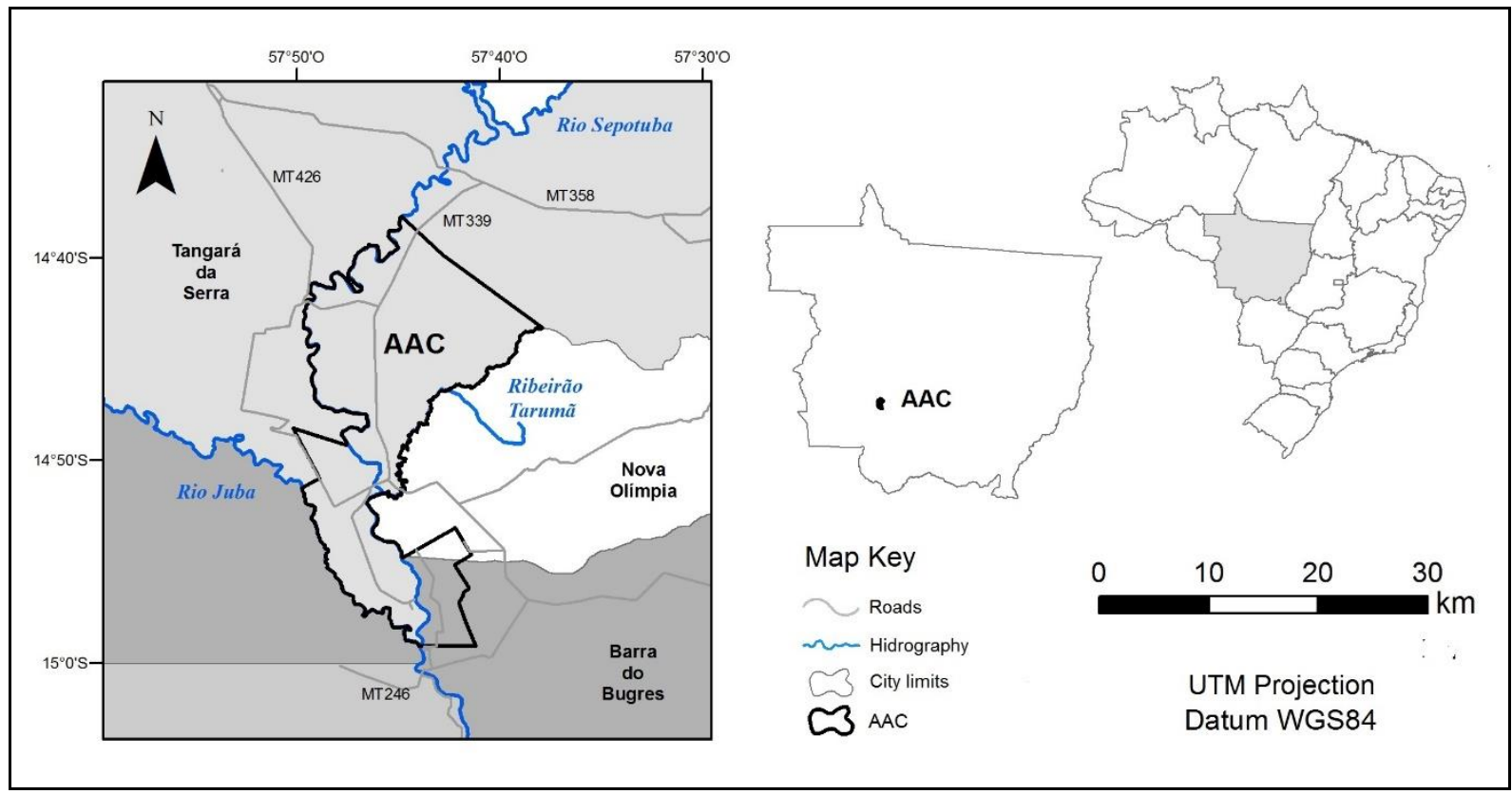

Source: Authors.

In the area in question, for greater representativity of the characteristics of water quality, five sample collection points for surface water (collected from the river banks) and five for groundwater (among shallow and deep wells) were defined in the contribution area of the Sepotuba and Juba rivers and the Tarumã Creek in the portion which bathes the AAC. The 29 collection points were identified as represented in Table 1. 
Table 1 - Location area, identification code and geographic coordinates of collection points. The first letter in the identification code represents river $(\mathrm{R})$ and well $(\mathrm{W})$.

\begin{tabular}{|c|c|c|c|}
\hline \multirow{2}{*}{ Area } & \multirow{2}{*}{ Code } & \multicolumn{2}{|c|}{ Geographic Coordinates } \\
\hline & & Latitude & Longitude \\
\hline \multirow{5}{*}{ Sepotuba River } & SR1 & $14^{\circ} 36^{\prime} 29.04^{\prime \prime} \mathrm{S}$ & $57^{\circ} 44^{\prime} 0.42^{\prime \prime} \mathrm{W}$ \\
\hline & $\mathrm{SR} 2$ & $14^{\circ} 44^{\prime} 3.93 ” \mathrm{~s}$ & $57^{\circ} 49^{\prime} 27.42^{\prime \prime} \mathrm{W}$ \\
\hline & SR3 & $14^{\circ} 48^{\prime} 23.46^{\prime \prime} \mathrm{S}$ & $57^{\circ} 46^{\prime} 37.62^{\prime \prime} \mathrm{W}$ \\
\hline & SR4 & $14^{\circ} 51^{\prime} 15.24^{\prime} \mathrm{S}$ & $57^{\circ} 46^{\prime} 14.58^{\prime \prime} \mathrm{W}$ \\
\hline & SR5 & $14^{\circ} 59^{\prime} 9.78^{\prime \prime} \mathrm{S}$ & $57^{\circ} 43^{\prime} 57.72^{\prime \prime} \mathrm{W}$ \\
\hline \multirow{5}{*}{ Sepotuba Well } & SW1 & $14^{\circ} 39^{\prime} 30.36^{\prime \prime} \mathrm{S}$ & $57^{\circ} 44^{\prime} 43.02 ” \mathrm{~W}$ \\
\hline & SW2 & $14^{\circ} 43^{\prime} 0.84^{\prime \prime} \mathrm{S}$ & $57^{\circ} 48^{\prime} 49.68^{\prime \prime} \mathrm{W}$ \\
\hline & SW3 & $14^{\circ} 48^{\prime} 36.48^{\prime \prime} \mathrm{S}$ & $57^{\circ} 46^{\prime} 30^{\prime \prime} \mathrm{W}$ \\
\hline & SW4 & $14^{\circ} 52,46.92^{\prime \prime} \mathrm{S}$ & $57^{\circ} 47^{\prime} 20.16^{\prime \prime} \mathrm{W}$ \\
\hline & SW5 & $14^{\circ} 58^{\prime} 6.42^{\prime \prime} \mathrm{S}$ & $57^{\circ} 44^{\prime} 3.12^{\prime \prime} \mathrm{W}$ \\
\hline \multirow{5}{*}{ Tarumã River } & TR1 & $14^{\circ} 41^{\prime} 52.698 ” \mathrm{~S}$ & $57^{\circ} 43^{\prime} 35.1^{\prime \prime} \mathrm{W}$ \\
\hline & TR2 & $14^{\circ} 43^{\prime} 3.84 \mathrm{~S}$ & $57^{\circ} 39^{\prime} 50.58^{\prime \prime} \mathrm{W}$ \\
\hline & TR3 & $14^{\circ} 45^{\prime} 27^{\prime \prime} \mathrm{S}$ & $57^{\circ} 40^{\prime} 42.06^{\prime \prime} \mathrm{W}$ \\
\hline & TR4 & $14^{\circ} 49^{\prime} 19.74^{\prime \prime} \mathrm{S}$ & $57^{\circ} 44^{\prime} 39.24^{\prime \prime} \mathrm{W}$ \\
\hline & TR5 & $14^{\circ} 51^{\prime} 37.44^{\prime \prime S}$ & $57^{\circ} 45^{\prime} 48.84^{\prime \prime} \mathrm{W}$ \\
\hline \multirow{4}{*}{ Tarumã Well } & TW2 & $14^{\circ} 44^{\prime} 14.52^{\prime} \mathrm{S}$ & $57^{\circ} 45^{\prime} 25.44^{\prime \prime} \mathrm{W}$ \\
\hline & TW3 & $14^{\circ} 43^{\prime} 47.52^{\prime \prime} \mathrm{S}$ & $57^{\circ} 40^{\circ} 26.64^{\prime \prime} \mathrm{W}$ \\
\hline & TW4 & $14^{\circ} 48^{\prime} 54.36^{\prime \prime} \mathrm{S}$ & $57^{\circ} 44^{\prime} 58.32^{\prime \prime} \mathrm{W}$ \\
\hline & TW5 & $14^{\circ} 51^{\prime} 43.02 ” \mathrm{~S}$ & $57^{\circ} 45^{\prime} 54.54 ” \mathrm{~W}$ \\
\hline \multirow{5}{*}{ Juba River } & JR1 & $14^{\circ} 51^{\prime} 22.5 ” \mathrm{~S}$ & $57^{\circ} 49^{\prime} 44.94^{\prime \prime} \mathrm{W}$ \\
\hline & $\mathrm{JR} 2$ & $14^{\circ} 54^{\prime} 9.12^{\prime \prime} \mathrm{S}$ & $57^{\circ} 48^{\prime} 39.6^{\prime \prime} \mathrm{W}$ \\
\hline & JR3 & $14^{\circ} 56^{\prime} 40.5^{\prime \prime} \mathrm{S}$ & $57^{\circ} 47^{\prime} 14.94 ” \mathrm{~W}$ \\
\hline & $\mathrm{JR} 4$ & $14^{\circ} 58^{\prime} 20.4^{\prime \prime} \mathrm{S}$ & $57^{\circ} 44^{\prime} 39.12^{\prime \prime} \mathrm{W}$ \\
\hline & JR5 & $14^{\circ} 59^{\prime} 5.58^{\prime \prime} \mathrm{S}$ & $57^{\circ} 44^{\prime} 0.24^{\prime \prime} \mathrm{W}$ \\
\hline \multirow{5}{*}{ Juba Well } & JW1 & $14^{\circ} 51^{\prime} 36.9^{\prime \prime} \mathrm{S}$ & $57^{\circ} 48^{\prime} 58.38^{\prime \prime} \mathrm{W}$ \\
\hline & JW2 & $14^{\circ} 54^{\prime} 6.6 ” \mathrm{~S}$ & $57^{\circ} 48^{\prime} 8.76^{\prime \prime} \mathrm{W}$ \\
\hline & JW3 & $14^{\circ} 56^{\prime} 34.2^{\prime \prime} \mathrm{S}$ & $57^{\circ} 47^{\prime} 1.2 ” \mathrm{~W}$ \\
\hline & JW4 & $14^{\circ} 57^{\prime} 7.74^{\prime \prime} \mathrm{S}$ & $57^{\circ} 45^{\prime} 56.52^{\prime \prime} \mathrm{W}$ \\
\hline & JW5 & $14^{\circ} 59^{\prime} 0.36^{\prime \prime} \mathrm{S}$ & $57^{\circ} 44^{\prime} 2.76^{\prime \prime} \mathrm{W}$ \\
\hline
\end{tabular}

Source: Authors.

The collection points were chosen in such a way as to guarantee the greatest possible collection uniformity in each unit, observing the area representativity and accessibility, for most rural properties are isolated by fences and entrance gates.

Sample collection was carried out monthly, between October 2014 and September 2015, in a previously identified, one-liter capacity, plastic recipient, considering water variability at the collection point. Immediately after collection, samples were stored in a polystyrene box with ice for transportation to the laboratory (Mantovani, et al., 2009).

Analyses were carried out in triplicate at the Chemistry Laboratory (Barra do Bugres Campus) and at the Soils Laboratory (Tangará da Serra Campus), both from the Mato Grosso State University (UNEMAT). The pH, EC (electric conductivity), $\mathrm{Na}^{+}$(sodium), $\mathrm{Ca}^{2+}$ (calcium), $\mathrm{Mg}^{2+}$ (magnesium), $\mathrm{Cl}^{-}$(chloride), and $\mathrm{HCO}^{3-}$ (bicarbonate) variables were determined with specific equipment and titration analyses as reported in Table 2, in compliance with the methods described at the Standard Methods for Examination of Water and Wastewater (Apha 2005). Analyses were done 24 hours after collection at 
the latest, except $\mathrm{Na}^{+}$, for which a sample was frozen for later procedure.

Table 2 - Variables, methodologies and equipment used in water analyses.

\begin{tabular}{ccc}
\hline Variable & Method & Equipment \\
\hline $\mathrm{pH}$ & Potentiometric & $\mathrm{pH}$ meter \\
Electric conductivity & Platinum electrode & DM31 conductivity meter \\
$\mathrm{Na}^{+}$ & Flame photometry & 910 Analyser Photometer \\
$\mathrm{Ca}^{2+}$ & Titration & Burette, pipette and Erlenmeyer flask \\
$\mathrm{Mg}^{2+}$ & Titration & Burette, pipette and Erlenmeyer flask \\
$\mathrm{Cl}^{-}$ & Titration & Burette, pipette and Erlenmeyer flask \\
$\mathrm{HCO}_{3}^{-}$ & Titration & Burette, pipette and Erlenmeyer flask \\
\hline
\end{tabular}

Source: Authors.

The Sodium Adsorption Ratio (SAR) was calculated based on Equation 1 (Richards, 1954):

$$
R A S=\frac{\mathrm{Na}^{+}}{\sqrt{\frac{\mathrm{Ca} a^{2+}+M g^{2+}}{2}}}
$$

Where:

SAR - Sodium Adsorption Ratio;

$\mathrm{Na}^{+}-$sodium concentration in meq $\mathrm{L}^{-1}$;

$\mathrm{Ca}^{2+}$ - calcium concentration in meq $\mathrm{L}^{-1}$;

$\mathrm{Mg}^{2+}-$ magnesium concentration in meq $\mathrm{L}^{-1}$.

Absolute dada were organized in electronic spreadsheets for the calculation of the average or mean of the dry and wet periods, defined according to the Shapiro-Wilk test of normality at 5\% significance, and presented next to minimum and maximum values to allow a general view of the gathered data. Data were compared with the parameters established by Ayers e Westcot (1985) in order to check the degree of restriction to use related to salinization, toxicity, and alteration of the infiltration capacity of the soil. Statistical analysis was carried out in the environment in R, version 3.2.2 (R Development Core Team, 2015), via its base package.

The Piper diagram was used for a better visualization of the chemical composition of the waters. Waters for irrigation use were classified based on the diagram adopted by the United States Salinity Laboratory (USSL) (Richards, 1954).

\section{Results and Discussion}

The quality of surface waters and groundwater contained in the area of study generally present satisfactory characteristics for irrigation use with few restrictions. Results obtained from physical and chemical analyses are presented in Table 3. They demonstrate that the main restrictions to the use of the water in irrigation are due to electric conductivity, $\mathrm{pH}$ and SAR. 
Table 3 - Results of average or mean (M) according to the test of normality, minimum (Min.) and maximum (Max.) obtained for the variables of surface waters and groundwater, and respective month of occurrence (Mon.), in the three areas.

\begin{tabular}{|c|c|c|c|c|}
\hline \multirow{2}{*}{ Variables } & \multirow{2}{*}{ Source } & \multirow{2}{*}{ Compartment } & \multicolumn{2}{|r|}{ Wet period } \\
\hline & & & $\mathrm{M}$ & Min. - Max. \\
\hline \multirow{6}{*}{$\mathrm{pH}$} & \multirow{2}{*}{ Juba } & Surface & 7.26 & 5.31 (Mar.) - 8.12 (Dec.) \\
\hline & & Groundwater & 6.04 & 5.44 (Apr.) - 7.79 (Mar.) \\
\hline & \multirow{2}{*}{ Sepotuba } & Surface & 7.35 & 4.79 (Jan.) - 8.33 (Dec.) \\
\hline & & Groundwater & 7.42 & 5.39 (Mar.) - 10.49 (Dec.) \\
\hline & \multirow{2}{*}{ Tarumã } & Surface & 7.45 & 5.95 (Oct.) - 8.20 (Oct.) \\
\hline & & Groundwater & $7.71 *$ & 7.06 (Apr.) - 8.53 (Sept.) \\
\hline \multirow{6}{*}{$\begin{array}{c}\mathrm{HCO}^{3-} \\
\left(\mathrm{meq} \mathrm{L}^{-1}\right)\end{array}$} & \multirow{2}{*}{ Juba } & Surface & 0.02 & 0.003 (Oct.) - 0.03 (Jan.) \\
\hline & & Groundwater & 0.02 & 0.005 (May) - 0.13 (Sept.) \\
\hline & \multirow{2}{*}{ Sepotuba } & Surface & 0.01 & 0.005 (May) - 0.06 (Apr.) \\
\hline & & Groundwater & 0.07 & 0.005 (May) - 0.76 (Apr.) \\
\hline & \multirow{2}{*}{ Tarumã } & Surface & 0.02 & 0.01 (May) - 0.10 (Apr.) \\
\hline & & Groundwater & 0.07 & 0.01 (Oct.) - 0.90 (Apr.) \\
\hline \multirow{6}{*}{$\begin{array}{c}\mathrm{Cl}^{-} \\
\left(\mathrm{meq} \mathrm{L}^{-1}\right)\end{array}$} & \multirow{2}{*}{ Juba } & Surface & 0.03 & 0.01 (Feb.) - 0.09 (Jan.) \\
\hline & & Groundwater & 0.03 & 0.01 (Jul.) - 0.32 (Nov.) \\
\hline & \multirow{2}{*}{ Sepotuba } & Surface & 0.03 & 0.01 (May) - 0.09 (Sept.) \\
\hline & & Groundwater & 0.05 & 0.01 (Feb.) - 0.26 (Jan.) \\
\hline & \multirow{2}{*}{ Tarumã } & Surface & 0.03 & 0.01 (May) - 0.09 (Jan.) \\
\hline & & Groundwater & 0.04 & 0.01 (May) - 0.14 (Jan.) \\
\hline \multirow{6}{*}{$\begin{array}{c}\mathrm{Na}^{+} \\
\left(\mathrm{meq} \mathrm{L} \mathrm{L}^{-1}\right)\end{array}$} & \multirow{2}{*}{ Juba } & Surface & 0.02 & 0.001 (Jan.) - 0.33 (Jul.) \\
\hline & & Groundwater & 0.24 & 0.04 (Mar.) - 0.90 (May) \\
\hline & \multirow{2}{*}{ Sepotuba } & Surface & 0.03 & 0.00 (Mar.) - 0.11 (Aug.) \\
\hline & & Groundwater & 1.22 & 0.01 (Jan.) - 2.50 (Jun.) \\
\hline & \multirow{2}{*}{ Tarumã } & Surface & 0.06 & 0.01 (Feb.) - 0.46 (Aug.) \\
\hline & & Groundwater & $1.55^{*}$ & 0.17 (Mar.) - 2.59 (Jun.) \\
\hline \multirow{6}{*}{$\begin{array}{c}\mathrm{Ca}^{2+} \\
\left(\mathrm{meq} \mathrm{L}^{-1}\right)\end{array}$} & \multirow{2}{*}{ Juba } & Surface & 0.02 & 0.00 (Aug.) - 0.12 (Dec.) \\
\hline & & Groundwater & 0.02 & 0.01 (Oct.) - 0.56 (Sept.) \\
\hline & & Surface & 0.02 & 0.00 (Aug.) - 0.12 (Dec.) \\
\hline & Sepotuba & Groundwater & 0.03 & 0.00 (Apr.) - 0.24 (Sept.) \\
\hline & & Surface & 0.02 & 0.00 (Aug.) - 0.08 (Nov.) \\
\hline & Tarumã & Groundwater & 0.06 & 0.01 (Aug.) - 1.11 (Dec.) \\
\hline & Jub? & Surface & 0.01 & 0.00 (Oct.) - 0.12 (Nov.) \\
\hline & Juba & Groundwater & 0.03 & 0.00 (Dec.) - 0.28 (Sept.) \\
\hline $\mathrm{Mg}^{2+}$ & & Surface & 0.00 & 0.00 (Dec.) - 0.15 (Nov.) \\
\hline$\left(\operatorname{meq~L^{-1}}\right)$ & Sepotuba & Groundwater & 0.02 & 0.00 (Dec.) - 0.24 (Sept.) \\
\hline & & Surface & 0.01 & 0.00 (Dec.) -0.21 (Dec.) \\
\hline & Tarumã & Groundwater & 0.06 & 0.00 (Jun.) -1.26 (Dec.) \\
\hline & & Surface & 0.14 & 0.01 (Jan.) - 2.73 (Jul.) \\
\hline & Juba & Groundwater & 1.14 & 0.36 (Mar.) - 4.42 (May) \\
\hline & & Surface & 0.18 & 0.003 (Mar.) - 1.04 (Aug.) \\
\hline SAR & Sepotuba & Groundwater & 3.73 & 0.04 (Jan.) - 23.61 (Jun.) \\
\hline & & Surface & 0.40 & 0.08 (Feb.) - 3.17 (Oct.) \\
\hline & Tarumã & Groundwater & 4.54 & 1.34 (Oct.) - 20.79 (Jun.) \\
\hline & & Surface & 0.01 & 0.005 (Sept.) - 0.03 (Apr.) \\
\hline & Juba & Groundwater & 0.01 & 0.01 (Jul.) - 0.22 (May) \\
\hline $\mathrm{EC}$ & & Surface & 0.02 & 0.01 (Aug.) - 0.06 (Mar.) \\
\hline$\left(\mathrm{dS} \mathrm{m} \mathrm{m}^{-1}\right)$ & Sepotuba & Groundwater & 0.40 & 0.02 (Aug.) - 0.55 (Jul.) \\
\hline & & Surface & $0.05 *$ & 0.01 (Sept.) - 0.09 (Sept.) \\
\hline & Tarumã & Groundwater & 0.40 & 0.14 (Mar.) - 1.50 (Oct.) \\
\hline
\end{tabular}

* Variables which presented normality ( $>>0.05)$. Source: Authors.

\section{pH Analysis}

The $\mathrm{pH}$ range considered adequate for the use of water in irrigation is between 6.5 and 8.4. $\mathrm{pH}$ values above or below these limits may result in equipment corrosion and may cause precipitation of some salts, which interferes in the water-soilplant relationship (Cunha, et al., 2014).

The surface water sources had a pH below 6.5. In the Sepotuba River, the value 4.79 was measured in the first collection point in January. In the Tarumã Creek, the measurement of pH 5.95 in October refers to the collection point which represents the waters coming from the Lambari and Russo brooks, which drain the waters flowing on the Serra de Tapirapuã 
slopes. In the Juba River, pH 5.31 was observed in the third collection point in March. As there was no repetition of these values below the ideal range, they may be considered isolated events and irrelevant to this study.

To the exception of the isolated measurements referred above, the $\mathrm{pH}$ of the surface water sources contained in the AAC area stayed within the range considered ideal. Donadio et al. (2005), evaluating surface sources in the Rico Brook basin, located in the Northeast of the state of São Paulo, observed that the $\mathrm{pH}$ measurements do not vary much between the dry and wet periods, supporting the data obtained.

The Tarumã Creek had a different behavior in relation to the others. The $\mathrm{pH}$ for the wet period was lower than in the dry period. A similar behavior was detected by Franco and Hernandez (2009) in four out of the five points collected in surface waters in the Coqueiro Creek micro-basin, located in the Northwest of the state of São Paulo.

The $\mathrm{pH}$ of shallow wells remained below 6.5 during all the measurement period. In the deep wells, the $\mathrm{pH}$ remained within the range considered ideal, except in SW4 and TW4, in which pH values were found above the limit, that is, 8.4, especially during the period of drought. Oliveira and Maia (1998) observed higher $\mathrm{pH}$ values in wells in the Chapada do Apodi region, in the state of Rio Grande do Norte, due to the presence of calcareous formations, which may explain the values obtained in the SW4 and TW4 wells, since that kind of formation is also present in the AAC region.

The use of dripping irrigation systems requires water with specific characteristics. The risk of clogging is low for $\mathrm{pH}$ below 7.0, moderate between 7.0 and 8.0, and severe above 8.0 (Goyal, et al., 2015). In this sense, the re-evaluation of $\mathrm{pH}$ values pointed to the need for attention in the use of that kind of system, since most of the evaluated points range between 7.0 and 8.0, and in the SW3, SW4, TW3 and TW4 wells values above 8.0 were frequent. In these points, the use of water in surface or sprinkler irrigation may enable the development of agricultural activities, since those systems are less demanding.

\section{Bicarbonate}

Bicarbonate is an anion with high solubility in water. Thus, the high volume of water crossing the soil and in contact with rocks might guarantee transport of this anion in a larger amount, which would justify the increase in its concentration during the wet period (Meireles, et al., 2010).

The concentration of bicarbonate anion does not pose a restriction on the use of the evaluated waters for surface irrigation $\left(<1,5 \mathrm{meq} \mathrm{L}^{-1}\right)$. However, according to Ayers and Westcot (1985), the presence of bicarbonate in water, even in low concentrations, may be a problem when used in sprinkler irrigation systems in conditions of low relative humidity and high evaporation rate. A deposit of salts (a white layer) is formed on fruits or leaves, aesthetically influencing the produce presentation, which may interfere in its trade. In the dry period, the studied region presents low relative humidity and high evapotranspiration, thus indicating the need for attention to this aspect in the cultivation of fruits and vegetables.

In high concentrations, bicarbonate tends to react with calcium and magnesium, precipitating them in the form of carbonates, which results in a nutritional imbalance in soil structure. This happens because the relative concentration of sodium increases and, therefore, a larger dispersion of clays happens in the soil (Arraes, et al., 2009; Maia, et al., 2012). This event, however, has a low perspective of happening in the AAC area, due to the low concentrations of bicarbonate verified.

\section{Chlorides}

Chloride anion is not easily adsorbed by soil particles; however, due to its high mobility, it is readily absorbed by plants and transported by transpiration stream up to the leaves, where it accumulates, thus causing the effect known as chlorosis.

Plants in general absorb amounts of chlorine in excess; that is, above their metabolic needs. Ferreira et al. (2007), studying the influence of salinity on corn production, observed that chlorine level increased from 120 days after planting, and 
that production was reduced due to increase in salinity.

In the evaluated samples, chloride concentrations indicated that there is no restriction to the use of these waters in surface or sprinkler irrigation systems, since they remained below 4.0 and $3.0 \mathrm{meq} \mathrm{L}^{-1}$ respectively.

Although the concentrations of chlorides and bicarbonate, individually, have not indicated restrictions to the use of the AAC waters for irrigation, it is highly important to evaluate the relationship between bicarbonate and chlorine. The concentration of $\mathrm{Cl}^{-}$is directly proportional to electric conductivity. Thus, the lower the electric conductivity, the higher the $\mathrm{HCO} 3 / \mathrm{Cl}^{-}$relation, and, therefore, $\mathrm{pH}$ may increase and result in reduction of availability of some elements in the soil, thus causing nutrient deficiency (Maia, et al., 2012).

\section{Sodium}

As observed, there was an increase in sodium concentration from the wet to the dry period in surface water and groundwater sources due to intense evaporation, which consequently promotes its concentration in the environment (Meireles, et al., 2010).

The amount of sodium in the soil and/or in the water may be toxic to some kinds of plants when it is absorbed. The application of water with high sodium concentrations onto the aerial part promotes direct absorption by leaves, which may be a problem for sensitive crops such as citrus, for instance (Brito \& Andrade, 2010).

In all evaluations, the highest observed sodium concentration was 2.59 meq $\mathrm{L}^{-1}$ in a well in the Tarumã Creek area during the period of drought. It should be noted that the highest value among the surface sources was observed in the Tarumã

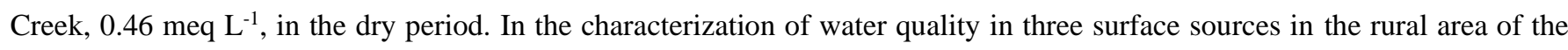
Federal District, Muniz et al. (2013) identified sodium concentrations which varied from 0.02 to $0.05 \mathrm{meq} \mathrm{L}^{-1}$, similar to the values measured in the Sepotuba River. Figueiredo Junior et al. (2013), evaluating the water quality on the Distrito de Irrigação Tabuleiros Litorâneos do Piauí (DITALPI), found out sodium concentrations similar to those observed in the Tarumã Creek, thus validating the values obtained in this study.

Sodium concentration up to 3.0 meq $\mathrm{L}^{-1}$ in irrigation water indicates that it may be used without risk of toxicity, thus characterizing the surface waters and groundwater in the AAC area as suitable for irrigation use.

\section{Calcium and Magnesium}

The presence of calcium and magnesium, mainly in groundwater, is due to the dissolution of rocks. As they both have similar chemical behavior, they are discussed together.

According to Ayers and Westcot (1985), calcium and magnesium are present in irrigation waters in 0-20 and 0-5 meq $\mathrm{L}^{-1}$ concentrations, respectively, and may be used without restrictions. As the highest concentration measured for calcium and magnesium did not exceed $1.1 \mathrm{meq} \mathrm{L}^{-1}$, it may be stated that the waters collected from the study area are $100 \%$ suitable for use. As Moura et al. (2011) were evaluating the water from the Cinturão Verde Creek micro-basin, in the municipality of Ilha Solteira, São Paulo State, the researchers observed that calcium remained within the recommended parameter in 100\% of the samples, thus corroborating this study. In that research, the concentration of magnesium exceeded 5 meq $\mathrm{L}^{-1}$ in two out of the three evaluated points, thus representing risk of efficiency reduction of irrigation systems due to the precipitation of magnesium. This fact, however, would not happen at AAC, since the established concentration of magnesium is very low.

The infiltration capacity of rainwater or waters applied by irrigation systems is related to the concentration of calcium and magnesium in relation to the concentration of sodium, which is expressed by the SAR discussed below. 


\section{SAR}

Although the concentration of sodium detected in the waters of the AAC area is not enough to cause toxicity problems, its relation to the concentrations of calcium and magnesium suggests serious risk of sodium toxicity. SAR reached 23.61 and 20.79 in the wells of the Sepotuba River and the Tarumã Creek areas, respectively, during the dry period.

High concentrations of sodium, in relation to the concentrations of calcium and magnesium, favor alterations in soil structure, thus influencing its infiltration capacity. Sodium is a dispersing agent that contributes to the breakdown of soil particles, which, in turn, may block pores, thus making the passage of water difficult. Therefore, high concentrations of salts allied with low SAR may place a severe restriction on the use of a specific water source (Oliveira, et al., 2000).

All samples collected from the surface water sources suggested an important level of restriction on their use concerning soil infiltration. The SAR of surface waters was lower than the one of groundwater, except in the Juba River, in which the river overcame the wells in both periods. The concentration of sodium in this river increased and calcium decreased, while the concentration of magnesium remained constant from the wet to the dry period, in conditions of low electric conductivity, which resulted in increase in SAR. The concentrations of calcium and magnesium in the wells increased, whereas the concentration of sodium remained constant, thus causing reduction in SAR.

A great variation regarding this factor was observed among the wells. A significant level of restriction predominated in groundwater in both periods, mainly in shallow wells. The SW2, SW3, TW3 and TW5 wells kept moderate restriction, whereas the TW2 and JW2 wells posed serious risk regarding infiltration capacity in all measurements.

The water sources which presented serious risk to the infiltration capacity of the soil should be utilized in irrigation systems which do not use large volumes of water, in order to avoid sealing of the more superficial layers and, therefore, water accumulation on the surface, sheet erosion, among others.

\section{Electric conductivity}

The electric conductivity of groundwater was higher than the one of surface water. Surface water sources do not present any degree of restriction to their use regarding soil salinity $\left(\mathrm{EC}<0.7 \mathrm{dS} \mathrm{m}{ }^{-1}\right)$. However, one must pay attention to the TW3 well, whose electric conductivity remained over $0.6 \mathrm{dS} \mathrm{m}{ }^{-1}$, from which Zocoler et al. (2015) observed partial clogging in drip tubing. This fact does not prevent the use of the well, but points to the need for attention to its usage and a potential reduction of the useful life of the equipment.

Besides soil salinization, the use of waters with high EC may negatively interfere with the development of several crops, since the presence of salts in the soil matrix changes osmotic balance, thus influencing their absorption (Nobre, et al., 2014; Oliveira, et al., 2014; Silva, et al., 2014). In this sense, the low electric conductivity values observed in both surface water and groundwater sources in the AAC area indicate that there is no risk of soil salinization in both periods.

In Table 4, some crops are listed according to their tolerance to salinity. Water is considered inadequate when salinity is above $10 \mathrm{dS} \mathrm{m}^{-1}$. 
Table 4 - Crops and tolerance to salinity.

\begin{tabular}{|c|c|c|c|c|}
\hline & $\begin{array}{c}\text { Sensitive } \\
\left(<1.3 \mathrm{dS} \mathrm{m}^{-1}\right)\end{array}$ & $\begin{array}{l}\text { Moderately sensitive } \\
\quad\left(1.3-3.0 \mathrm{~S} \mathrm{~m}^{-1}\right)\end{array}$ & $\begin{array}{l}\text { Moderately tolerant } \\
\left(3.0-6.0 \mathrm{dS} \mathrm{m}^{-1}\right)\end{array}$ & $\begin{array}{c}\text { Tolerant } \\
\left(6.0-10.0 \mathrm{dS} \mathrm{m}^{-1}\right)\end{array}$ \\
\hline \multirow{4}{*}{$\begin{array}{l}\text { Fiber, seeds and } \\
\text { sugar crops }\end{array}$} & & Sugar cane & Sorghum & Cotton \\
\hline & & Fava bean & Triticale & Beet \\
\hline & & Castor bean & Wheat & \\
\hline & & Corn & & \\
\hline \multirow[t]{8}{*}{ Vegetables } & Bean & Broccoli & Beet & Asparagus \\
\hline & Carrot & Cabbage & Zucchini & \\
\hline & Onion & Cauliflower & & \\
\hline & & Lettuce & & \\
\hline & & Bell pepper & & \\
\hline & & Squash & & \\
\hline & & Spinach & & \\
\hline & & Sweet potato & & \\
\hline \multirow[t]{6}{*}{ Fruits } & Lime & Grape & Fig & Date \\
\hline & Mango & & Papaya & \\
\hline & Orange & & Pineapple & \\
\hline & Passion fruit & & Pomegranate & \\
\hline & Peach & & & \\
\hline & Tangerine & & & \\
\hline
\end{tabular}

Source: Adapted from Ayers and Westcot (1985).

During the visits to the AAC area, it was possible to observe the cultivation of corn, bean, carrot, lettuce, bell pepper, squash, sweet potato, zucchini, lime, mango, orange, passion fruit, pineapple, among others, most of them carried out without the use of irrigation systems. The evaluation of water quality is the first step towards the choice and further implementation of irrigation systems, which motivated this study.

\section{Piper diagram}

Figure 2 presents the Piper diagram for surface waters and groundwater in the wet and dry periods, allowing a better view of their chemical composition. Sodic waters predominated over cations in the group, with 97\%, whereas mixed waters were $3 \%$. Chloride waters (62\%) predominated over bicarbonate waters (38\%) among anions. The combination of cations and anions results in 59\% chloride-sodic waters, $38 \%$ bicarbonate-sodic waters, and 3\% mixed chloride waters. 
Figure 2 - Piper Diagram for surface waters and groundwater in the Antônio Conselheiro Settlement (AAC) area, in the wet and dry periods.

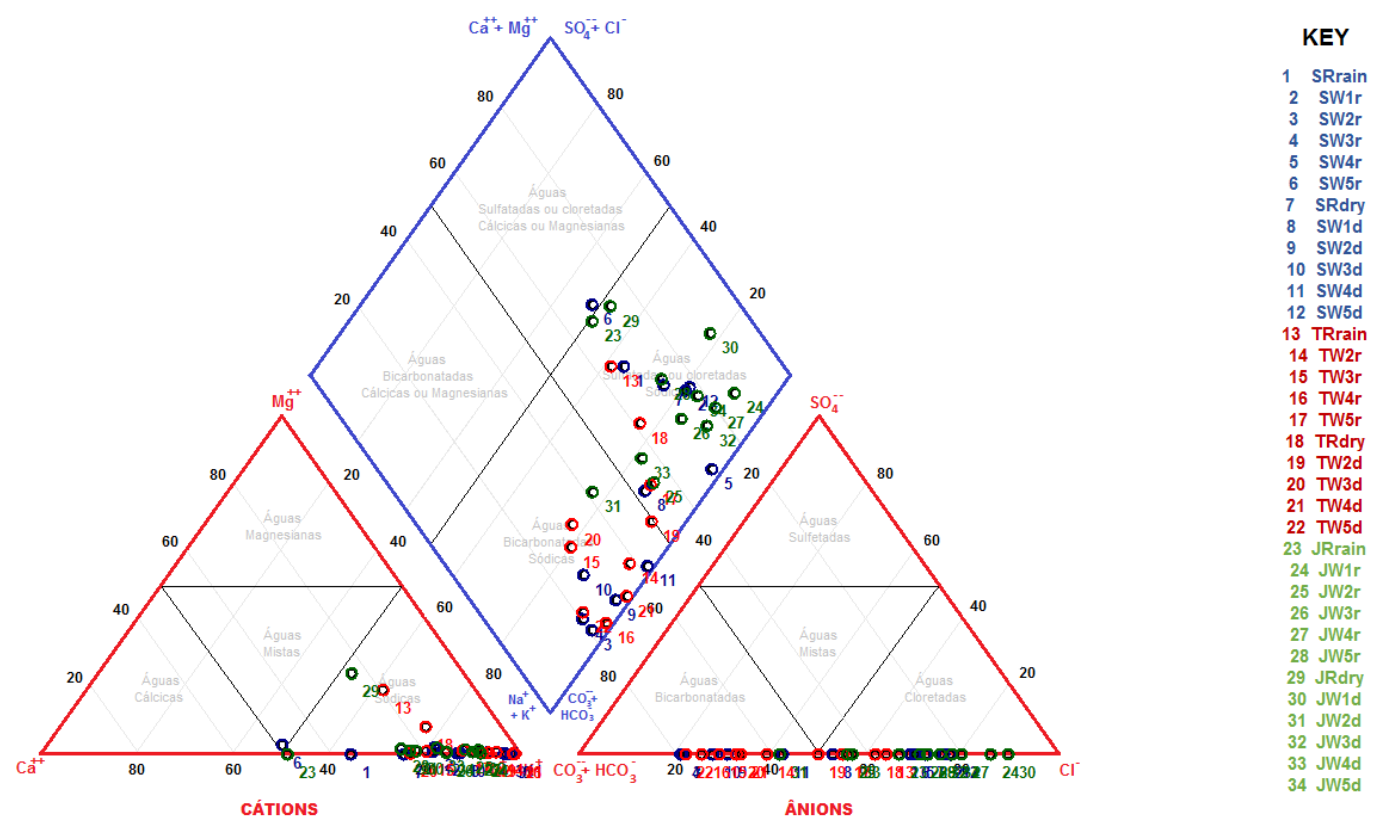

Source: Authors.

Observing the relation between the wet and dry periods in the Piper diagram, few changes are noticeable in the chemical composition of the waters of rivers and wells. The Tarumã Creek was the only surface water source whose alteration of composition reflected upon class alteration. Among the wells, it is important to highlight SW5, which is shallow, and therefore more susceptible to changes due to rainfall rates, and JW2, the only tubular well in the Juba River area. The composition of each individual area may be seen in Appendix 1.

The use of the Piper diagram in studies on water quality (Aly, et al., 2013; Kumar, 2013; Reginato, et al., 2013) shows its importance to the interpretation of results, mainly among numerous samples, among which disparities and similarities may be verified (Dauda \& Habib, 2015).

\section{United States Salinity Laboratory (USSL) Diagram}

Figure 3 presents the USSL diagram for the classification of surface waters and groundwater in the AAC area regarding the risks of sodicity and salinization. The diagram shows that most of the studied points have no, low or medium risk of sodicity or salinization. 
Figure 3 - USSL diagram for classification of surface waters and groundwater in the Antônio Conselheiro Settlement (AAC) area regarding risk of sodicity and salinization.

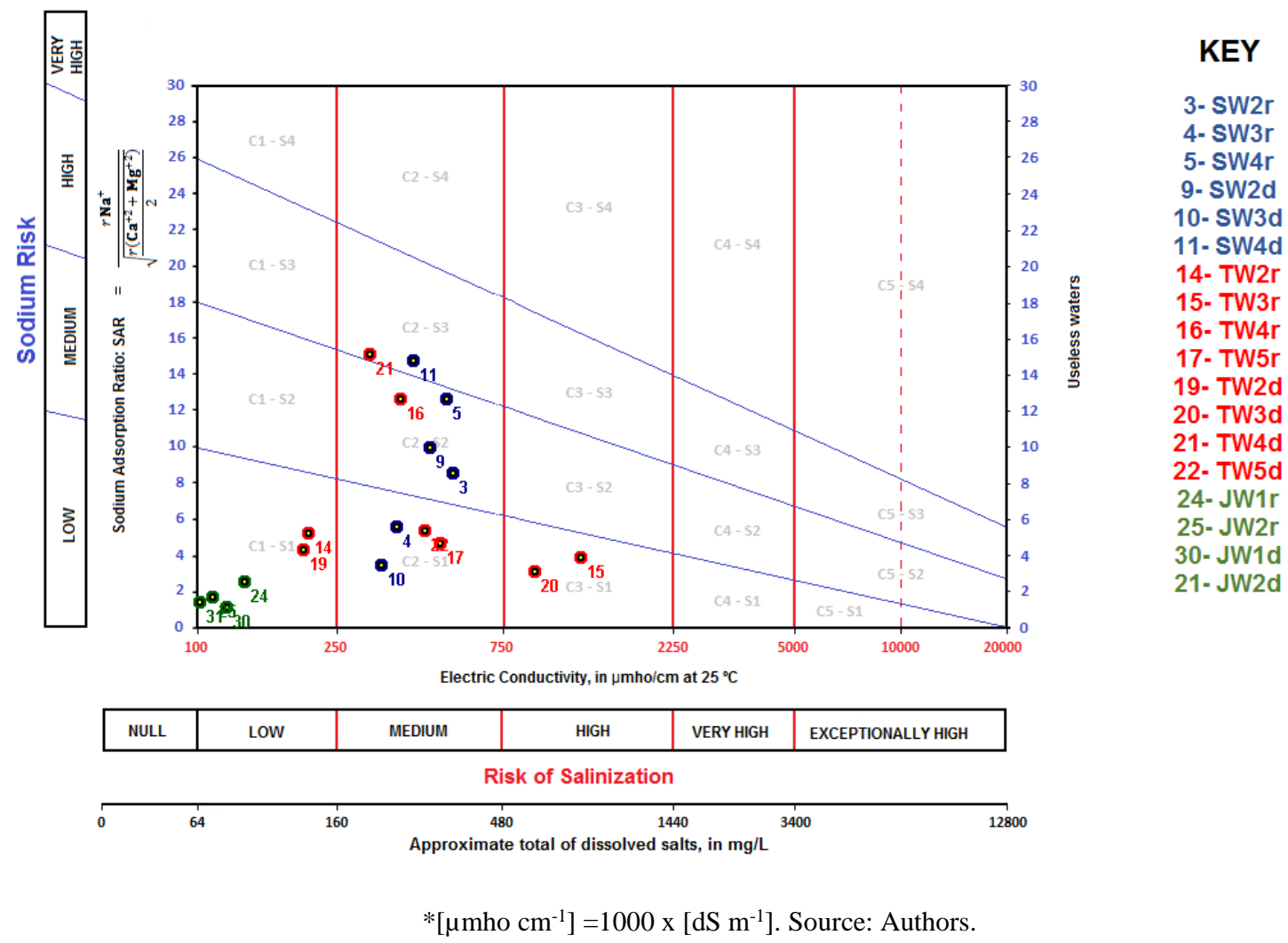

The surface waters of the three surface sources and the groundwater from the SW1, SW5, JW3, JW4 and JW5 wells were classified as $\mathrm{C} 0$-S1 for not presenting risk of salinization, either in the wet or in the dry period, since their electric

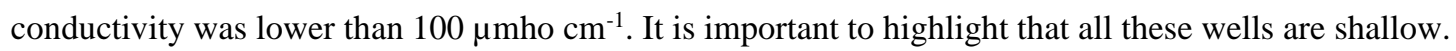

The JW1 and JW2 wells remained in the C1-S1 class in both periods.

Regarding the deep wells SW2 (C2-S2), SW3 (C2-S1) and SW4 (C2-S2), the same classifications observed in the wet period remained in the dry one. The only exception was the SW4 well, which turned into S3 due to temperature increase and lower groundwater recharge volume.

The classification of the TW2 well remained C1-S1. Between the wet and dry periods, the TW3 and TW4 wells did not have their classifications altered. However, the TW3 well poses medium risk of sodicity and salinization (C3-S2), whereas the TW4 well is at medium risk of sodicity and high risk of salinization (C2-S2).

Table 5 summarizes the classes identified in the USSL diagram regarding their frequency. It is possible to observe the predominance of waters of good or excellent quality for use in irrigation. 
Table 5 - Summary of the classification of surface waters and groundwater in the Antônio Conselheiro Settlement (AAC) area based on the one proposed by the USSL (Richards, 1954).

\begin{tabular}{|c|c|c|c|c|}
\hline \multirow{2}{*}{ Classes } & \multicolumn{2}{|c|}{ Risk } & \multirow{2}{*}{ Water quality } & \multirow{2}{*}{$\begin{array}{c}\text { Frequency } \\
\%\end{array}$} \\
\hline & Salinity & Sodicity & & \\
\hline $\mathrm{C} 0-\mathrm{S} 1$ & Null & Low & Excellent & 47.0 \\
\hline $\mathrm{C} 1-\mathrm{S} 1$ & Low & Low & Excellent & 17.6 \\
\hline $\mathrm{C} 2-\mathrm{S} 1$ & Medium & Low & Good & 11.8 \\
\hline $\mathrm{C} 2-\mathrm{S} 2$ & Medium & Medium & Good & 11.8 \\
\hline $\mathrm{C} 2-\mathrm{S} 3$ & Medium & High & $\mathrm{Bad}$ & 5.9 \\
\hline $\mathrm{C} 3-\mathrm{S} 1$ & High & Medium & Regular & 5.9 \\
\hline
\end{tabular}

Source: Authors.

It is important to emphasize that $88.2 \%$ of the samples were classified as excellent or good, which shows the great potential for use of the AAC area waters for irrigation, based on the classification proposed by Richards (1954). On the other hand, in $11.8 \%$ of the collection points water quality was regular or bad due to high risk of salinity or sodicity.

Based on the data presented by the water analyses bulletins of the Escola Superior de Agricultura de Mossoró (ESAM)'s Water and Soil Analysis Laboratory (LAAFS), Morais et al. (1998) assessed the quality of water for irrigation purposes in the state of Rio Grande do Norte and other locations in the Northeast region. They found out that $63.41 \%$ were classified as terrible or bad, whereas 36.59\% were considered good or excellent. The study carried out by Galvão et al. (2008) in the sedimentary basin of the Peixe River, located in the state of Paraíba, showed that the most frequent classes were C3-S1 and $\mathrm{C} 3-\mathrm{S} 2$, whereas in the AAC area $\mathrm{C} 0-\mathrm{S} 1$ was predominant, followed by $\mathrm{C} 1-\mathrm{S} 1$. Those differences may be associated with such factors as the local geology and the warmer climate in the region where the Peixe River basin is located.

The high percentage of waters of good quality for irrigation is a special feature compared with other regions, and it indicates there is potential for installation of irrigation projects without major problems. Table 6 summarizes the places where some kind of restriction to the use of water was observed, and its relation to irrigation systems.

Table 6 - Relationship among areas, water sources, periods, and types of irrigation systems.

\begin{tabular}{|c|c|c|c|c|c|}
\hline \multirow{2}{*}{ Area } & \multirow{2}{*}{ Source } & \multirow{2}{*}{ Period } & \multicolumn{3}{|c|}{ Irrigation systems } \\
\hline & & & Surface & Sprinkler & Localized \\
\hline \multirow{4}{*}{ Juba } & \multirow{2}{*}{ Surface } & Wet & $\mathrm{x}$ & & \\
\hline & & Dry & $\mathrm{x}$ & & \\
\hline & \multirow{2}{*}{ Groundwater } & Wet & $\mathrm{x}$ & & $\mathrm{x}$ \\
\hline & & Dry & $\mathrm{x}$ & & $\mathrm{x}$ \\
\hline \multirow{4}{*}{ Sepotuba } & \multirow{2}{*}{ Surface } & Wet & $\mathrm{x}$ & & \\
\hline & & Dry & $\mathrm{x}$ & & \\
\hline & \multirow{2}{*}{ Groundwater } & Wet & $\mathrm{x}$ & $\mathrm{x}$ & $\mathrm{x}$ \\
\hline & & Dry & $\mathrm{x}$ & $\mathrm{x}$ & $\mathrm{x}$ \\
\hline \multirow{4}{*}{ Tarumã } & \multirow{2}{*}{ Surface } & Wet & $\mathrm{x}$ & & \\
\hline & & Dry & $\mathrm{x}$ & & \\
\hline & \multirow{2}{*}{ Groundwater } & Wet & $\mathrm{x}$ & $\mathrm{x}$ & $\mathrm{x}$ \\
\hline & & Dry & $\mathrm{x}$ & $\mathrm{x}$ & $\mathrm{x}$ \\
\hline
\end{tabular}

Source: Authors.

The high application rate required by surface irrigation systems depends on the water infiltration capacity in the soil, 
which presented moderate level of restriction for the Sepotuba and Tarumã groundwater, and severe level for the other sources in both periods. The low $\mathrm{pH}$ in the Juba groundwater, both in the wet and dry periods, restricts the use of localized irrigation systems. The risk of sodium toxicity in the Sepotuba and Tarumã groundwater makes the use of irrigation systems difficult. However, irrigation may be enabled with the implementation of filtration systems.

\section{Conclusion}

- Three out of the eight evaluated variables showed some kind of restriction to the use of water for irrigation in the AAC. They are: electric conductivity, $\mathrm{pH}$ and SAR;

- SAR indicated risk of toxicity and of alteration in the infiltration capacity of the soil in most points sampled in the AAC. In those points, one should choose irrigation systems which use lower volume of water;

- Surface waters and groundwater in the AAC area are good or excellent for irrigation use in $88.2 \%$ of the cases;

- Sprinkler and localized irrigation systems are the most suitable ones for the AAC area; surface irrigation should be avoided;

- The variability of results obtained in the AAC area demonstrates the need for evaluation of water quality before the implementation of any irrigation systems.

\section{References}

Aly, A., Alomran, A., Alwabel, M., Almahaini, A. \& Alamari, M. (2013). Hydrochemical and quality of water resources in Saudi Arabia groundwater: a comparative study of Riyadh and Al-Ahsa regions. Proceedings of the International Academy of Ecology and Environmental Scienses, 3(1), 42-51.

APHA - American Public Health Association; American Water Works Association. (2005). Standard methods for the examination of water and wastewater. 21st Ed. Washington, DC

Araújo, L. F., Lima, R. E. M., Costa, L. O., Silveira, E. M. C. \& Bezerra, M. A. (2014). Alocação de íons e crescimento de plantas de cajueiro anão-precoce irrigadas com água salina no campo. Revista Brasileira de Engenharia Agrícola e Ambiental, 18, 534-538

Arraes, F. D. D., Andrade, E. M. A., Palácio, H. A. Q., Frota Junior, J. I., \& Santos, J. C. N. (2009). Identification of determinant ions of surface water electric conductivity in the Curu Basin, Ceará State. Revista de Ciências Agrárias, 40(3), 346-355.

Ayers, R. S., \& Westcot, D. W. (1985). Water quality for Agriculture. Irrigation and Drainage Paper. FAO. http://www.fao.org/DOCReP/003/T0234e/T0234e00.htm.

Bazinet, N. L., Gilbert, B. M., \& Wallace, A. M. (2010). A comparison of urbanization effects on stream benthic macro invertebrates and water chemistry in an urban and an urbanizing basin in Southern Ontario, Canada. Water Quality Research Journal, 45(3), 327-341.

Brito, R. A. L., \& Andrade, C. L. T. (2010). Qualidade da água na agricultura e no ambiente. Informe Agropecuário, (31), 50-57.

Coelho, D. S., Simões, W. L., Mendes, M. A. S., Dantas, B. F., Rodrigues, J. A. S., \& Souza, M. A. (2014). Germinação e crescimento inicial de variedades de sorgo forrageiro submetidas ao estresse salino. Revista Brasileira de Engenharia Agrícola e Ambiental, 18(1), 25-30

Coelho, J. B. M., Barros, M. F. C., Bezerra Neto, E., \& Souza, E. R. (2014). Ponto de murcha permanente fisiológico e potencial osmótico de feijão caupi cultivado em solos salinizados. Revista Brasileira de Engenharia Agrícola e Ambiental, 18(7), 708-713.

Cunha, C. S. M., Hernandez, F. F. F., Silva, F. N., Escobar, M. E. O., Magalhães, D. R., \& Anjos, D. C. (2014). Relação entre solos afetados por sais e concentração de metais pesados em quatro perímetros irrigados no Ceará. Revista Brasileira de Engenharia Agrícola e Ambiental, $18,580-585$.

Dallacort, R., Martins, J. A., Inoue, M. H., Freitas, P. S. L., \& Coletti, A. J. (2011). Distribuição das chuvas no município de Tangará da Serra, médio norte do Estado de Mato Grosso, Brasil. Acta Scientiarum. Agronomy, 33(2), 193-200. https://doi.org/10.4025/actasciagron.v33i2.5838

Dauda, M., Habib, \& G. A. (2015). Graphical techniques of presentation of hydro-chemical data. Journal of Environment and Earth Science, 5(4), 66-75.

Diniz Neto, M. A., Silva, I. F., Cavalcante, L. F., Diniz, B. L. M. T., Silva, J. C. A., \& Silva, E. C. (2014). Mudas de oiticica irrigadas com águas salinas no solo com biofertilizante bovino e potássio. Revista Brasileira de Engenharia Agrícola e Ambiental, 18(1), 10-18.

Donadio, N. M. M., Galbiatti, J. A., \& Paula, R. C. (2005). Qualidade da água de nascentes com diferentes usos do solo na bacia hidrográfica do córrego Rico, São Paulo, Brasil. Revista Engenharia Agrícola, 25(1), 115-125.

Fernandes, M. A. B., Santiago, M. M. F., Gomes, D. F., Mendes Filho, J., Frischkorn, H., \& Lima, J. O. G. (2005). A origem dos cloretos nas águas subterrâneas na Chapada do Apodi - Ceará. Águas Subterrâneas, 19(1), 25-34. http://dx.doi.org/10.14295/ras.v19i1.1349. 
Ferreira, P. A., Garcia, G. O., Neves, J. C. L., Miranda, G. V., \& Santos, D. B. (2007). Produção relativa do milho e teores folheares de nitrogênio, fósforo, enxofre e cloro em função da salinidade do solo. Revista Ciência Agronômica, 38(1), 7-16.

Figueiredo Junior, L. G. M., Ferreira, J. R., Fernandes, C. N. V., Andrade, A. C., Azevedo, B. M., \& Rocha, K. (2013). Avaliação da qualidade da água no Distrito de Irrigação Tabuleiros Litorâneos do Piauí - DITALPI. Revista Brasileira da Agricultura Irrigada, 7(3), 213-233. http://dx.doi.org/10.7127/rbai.v7n300019.

Franco, R. A. M., \& Hernandez, F. B. T. (2009). Qualidade da água para irrigação na microbacia do Coqueiro, estado de São Paulo. Revista Brasileira de Engenharia Agrícola e Ambiental, 13(6), 772-780.

Frota Junior, J. I., Andrade, E. M., Meireles, A. C. M., Bezerra, A. M. E., \& Souza, B. F. S. (2007). Influência antrópica na adição de sais no trecho perenizado da bacia hidrográfica do Curu, Ceará. Revista Ciência Agronômica, 38(2), 142-148.

Gadanakis, Y., Bennett, R., Park, J., \& Areal, F. J. (2015). Improving productivity and water use efficiency: a case study of farms in England. Agricultural Water Management, 160, 22-32. http://dx.doi.org/10.1016/j.agwat.2015.06.020.

Galvão, M. J. T. G., Rocha, D. E. G. A., Amaral, C. A., \& Costa Filho, W. D. (2008). Hidrogeologia da bacia sedimentar do rio do Peixe - PB. XV Congresso Brasileiro de Águas Subterrâneas, 2008.

Goyal, M. R., Chavan, V. K., \& Tripathi, V. K. (2015). Principles and management of clogging in micro irrigation. Apple Academic Press, Canadá.

Kadyampakeni, D. M., Mloza-Banda, H. R., Singa, D. D., Mangisoni, J. H., Ferguson, A., \& Snapp, S. (2013). Agronomic and socio-economic analysis of water management techniques for dry season cultivation of common bean in Malawi. Irrigation Science, 31, 537-544. http://dx.doi.or/10.1007/s00271-0120333-5.

Kumar, P. J. S. (2013). Interpretation of groundwater chemistry using piper and chadha's diagrams: a comparative study from perambalur taluk. Elixir Geoscience, 54, 12.208-12.211.

Levidow, L., Zaccaria, D., Maia, R., Vivas, E., Todorovic, M., \& Scardigno, A. (2014). Improving water-efficient irrigation: prospects and difficulties of innovative practices. Agricultural Water Management, 146, 84-94. http://dx.doi.org/10.1016/j.agwat.2014.07.012.

Lima, G. S., Nobre, R. G., Gheyi, H. R., Soares, L. A. A., Lourenço, G. S., \& Silva, S. S. (2014). Aspectos de crescimento e produção da mamoneira irrigada com águas salinas e adubação nitrogenada. Revista Brasileira de Engenharia Agrícola e Ambiental, 18(6), 615-622.

Maia, C. E., Rodrigues, K. K. L., \& Lacerda, V. S. (2012). Relação entre bicarbonate e cloreto em águas para fins de irrigação. Irriga, Edição Especial, 206219.

Mantovani, E. C., Bernardo, S., \& Palaretti, L. F. Irrigação: princípios e métodos. 3. ed. Viçosa: Editora UFV, 2009

Meireles, A. C. M., Andrade, E. M., Chaves, L. C. G., Frischkorn, H., \& Crisostomo, L. A. (2010). A new proposal of the classification of irrigation water. Revista Ciência Agronômica, 41(3), 349-357.

Morais, E. R. C., Maia, C. E., \& Oliveira, M. (1998). Irrigation water quality in analytical samples of the soil and Geology Department Database, Escola Superior de Agricultura de Mossoró, Mossoró - RN. Caatinga, 11, 75-83

Moura, R. S., Hernandez, F. B. T., Leite, M. A., Franco, R. A. M., Feitosa, D. G., \& Machado, L. F. (2011). Qualidade da água para uso em irrigação na microbacia do córrego do cinturão verde, município de Ilha Solteira. Revista Brasileira de Agricultura Irrigada, 5(1), 68-74.

Muniz, D. H. F., Simplício, N. C. S., Rocha, F. R. M., Oliveira-Filho, E. C., \& Lima, J. E. F. W. (2013). Caracterização da qualidade da água superficial de três corpos hídricos rurais do Distrito Federal. In: XX Simpósio Brasileiro de Recursos Hídricos, 2013, Bento Gonçalves - RS. Anais. Bento Gonçalves: Associação Brasileira de Rescursos Hídricos, 2013, p. 1-8.

Nobre, R. G., Sousa, W. B., Lima, G. S., Gheyi, H. R., Dias, A. S., \& Pinheiro, F. W. A. (2014). Sources and doses of nitrogen in the production of sunflower plants irrigated with saline water. Revista Brasileira de Engenharia Agrícola e Ambiental, 18, 559-565.

Nóbrega, J. S., Lopes, K. P., Paiva, F. J. S., \& Silva, J. G., Dantas, M. V. (2020). Potencial fisiológico de sementes de melão pepino submetidas a salinidade. Research, Society and Development, 9 (7). http://dx.doi.org/10.33448/rsd-v9i7.3735

Oliveira, F. A., Medeiros, J. F., Alves, R. C., Linhares, P. S. F., Medeiros, A. M. A., \& Oliveira, M. K. T. (2014). Interação entre salinidade da água de irrigação e adubação nitrogenada na cultura da berinjela. Revista Brasileira de Engenharia Agrícola e Ambiental, 18(5), 480-486.

Oliveira, M., Maia, \& C. E. (1998). Qualidade físico-química da água para irrigação em diferentes aquíferos na área sedimentar do estado do Rio Grande do Norte. Revista Brasileira de Engenharia Agrícola e Ambiental, 2, 17-21.

Oliveira, R. A., Campelo, P. L. G., Matos, A. T., Martinez, M. A., \& Cecon, P. R. (2000). Influência da aplicação de águas residuárias de suinocultura na capacidade de infiltração de um solo podzólico vermelho-amarelo. Revista Brasileira de Engenharia Agrícola e Ambiental, 4, 263-267

Paz, V. P. S., Teodoro, R. E. F., \& Mendonça, F. C. (2000). Comunicado técnico. Recursos hídricos, agricultura irrigada e meio ambiente. Revista Brasileira de Engenharia Agrícola e Ambiental, 4(3), 465-473.

R Development Core Team (2015) A language and environment for statistical computing. Vienna: R Foundation for Statistical Computing.

Reginato, P. A. R., Ahlert, S., \& Schneider, V. E. (2013). Caracterização hidroquímica dos aquíferos fraturados da formação Serra Geral na região nordeste do estado do Rio Grande do Sul. Águas Subterrâneas, 27, 65-78 
Research, Society and Development, v. 11, n. 3, e42711327068, 2022

(CC BY 4.0) | ISSN 2525-3409 | DOI: http://dx.doi.org/10.33448/rsd-v11i3.27068

Richards, L. A. (1954). Diagnosis and improvement of saline and alkali soils. Washington: United States Department of Agriculture (Agricultural Handbook, $60)$

Seid, M., \& Genanew, T. (2013). Evaluation of soil and water salinity for irrigation in North-eastern Ethiopia: case study of Fursa small scale irrigation system in Awash Riber Basin. African Journal of Environmental Science and Technology, 7(5), 167-174. http://dx.doi.org/10.5897/AJEST2013.1464

Silva, E. L., Silva, K. A., Sousa, F. R. L., \& Tavares, F. B. R. (2019). A escassez hídrica na zona rural: o consumo de água sob a perspectiva dos agricultores de um assentamento no município de Pombal-PB. Research, Society and Development, 8(6). http://dx.doi.org/10.33448/rsd-v8i6.1038

Silva, J. L. A., Medeiros, J. F., Alves, S. S. V., Oliveira, F. A., Silva Junior, M. J., \& Nascimento, I. B. (2014). Uso de águas salinas como alternativa na irrigação e produção de forragem no semiárido nordestino. Revista Brasileira de Engenharia Agrícola e Ambiental, 18, 566-572.

Silva, V. T., Gava, R., Cotrim, M. F., Wassolowski, C. R., Teodoro, P. E., \& Snyder, R. L. (2020). Manejo da irrigação na cultura da soja em sistema de semeadura direta, sobre restos culturais de Brachiaria ruziziensis. Research, Society and Development, 9(6). http://dx.doi.org/10.33448/rsd-v9i6.3430

Zocoler, J. L., Ribeiro, P. H. P., Silva, N. F., Cunha, F. N., Teixeira, M. B., \& Soares, F. A. L. (2015). Desempenho de um sistema de irrigação por gotejamento com aplicação de água salina. Irriga, Edição especial, 234-247.

Zuffo, C. E., Abreu, F. A. M., Cavalcante, I. N., \& Nascimento, G. F. (2009). Águas subterrâneas em Rondônia: análise estatística de dados hidroquímicos, organolépticos e bacteriológicos. Revista do Instituto Geológico, 30(1/2), 45-59. 